\title{
An enquiry on poverty discourses in public theology for the calling of the church to respond to poverty: A case for the Africa Inland Church in Kenya
}

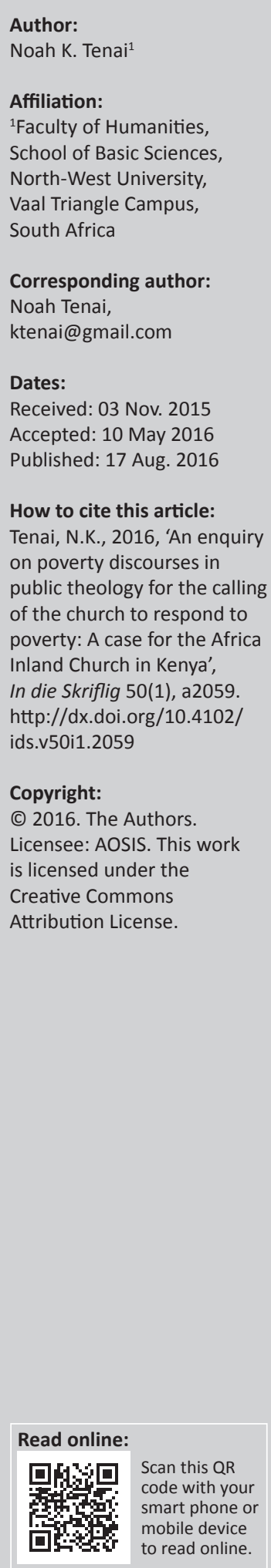

As an emergent and rapidly growing international field of study, public theology has its focus on how Christian faith and practice impact on ordinary life. Its principle concern is the well-being of society. In Africa, and in Kenya in particular, where poverty levels are still high, there is a need to enquire into the value and efficacy of the poverty discourses in public theology, for the calling of the church to respond to poverty. One of the main and fast growing churches in Kenya, the Africa Inland Church (AIC), has vast resources used for, amongst other things, various on-going work amidst the poor and the vulnerable in remote and poor areas. Due to the unrelenting nature of poverty in Kenya, the AIC needs a theological perspective, which is sufficiently sensitive to poverty and can enable it to respond to poverty more effectively. Public theology's emphasis on gaining an entrée into the public square and adopting the agenda of communities, including public theology's calling on churches to actively participate in rational and plausible public discourses, can assist the AIC to respond effectively to the challenge of poverty in Kenya.

\section{Background and introduction}

Churches continue to be at the forefront of several major movements for social change and the fight against poverty. From the establishment of the earliest orphanages, hospitals and public schools to the abolition of slavery and forced child labour, churches have responded to the cries of poverty and suffering (Frankema 2012:2; Garner 2000:313; Van Klinken 2010:446-447).

Various examples can be provided to demonstrate how Christians continue in contemporary times to shape and challenge the course of societies in socio-political and economic spheres. Examples include the fight against apartheid in South Africa, the movement against labour exploitation in South Korea, and the 2005 'Make Poverty History' campaign in the UK (Kim 2011:vii-viii, ix; Kim \& Kim 2008). Many churches around the world are making significant contributions to the wider society and the nation. They are not merely protecting their own immediate concerns, but are seeking the public good.

The seemingly endless presence of grinding poverty in the world and especially in Africa, begs the question as to whether the way in which churches conceptualise and respond to poverty has been effective. Churches need theologies that can enable them to respond more faithfully to the triune God regarding poverty in the world.

Various theologies have been developed over the last few decades, which have explicitly attempted to address social challenges such as poverty. Amongst these are the liberation theologies of Latin America and black theology, which developed in North America and South Africa. These two theologies are '... an interpretation of Christian faith out of the experience of the poor' and 'an attempt to read the Bible and key Christian doctrines with the eyes of the poor' (Berryman 1987:4). They are, however, not the focus of this article.

More recently, a new form or expression of (contextual) theology (all theology is contextual in one way or another as in Bevans 1996:3,15) has been developed, known as public theology. Representatives from 24 research institutions around the world met in 2007 in the USA to form a new research partnership called the Global Network for Public Theology (GNPT) - an academic research partnership that promotes theological contributions on public issues in a 'global' context. The aim of the GNPT is to conduct interdisciplinary research in theology and public issues in a global and local context. Various universities around the world have established public theology 
centres to address particular issues in their local and national contexts. However, they are increasingly interested in wider issues such as globalisation, climate change, poverty, civil society, human rights, gender and racial equality (Kim 2011:6).

Public theology in South Africa and Africa is gaining momentum as demonstrated by the founding of centres or research programmes for public theology at universities such as the Beyers Naudé Centre for Public Theology at the University of Stellenbosch, the Centre for Public Theology at the University of Pretoria, the Institute for Public Theology and Development Studies at the University of Mkar in Nigeria, and the Department of Religion and Theology at the University of the Western Cape.

This article therefore enquires into the potential of poverty discourses in public theology to assist churches, particularly the Africa Inland Church (AIC) in Kenya, in addressing the challenge of poverty. What are the implications and potential of poverty discourses in public theology to the calling of the AIC to address poverty in Kenya and in the world?

\section{The Africa Inland Church and social challenges in Kenya}

The AIC has a history of just over 120 years in Kenya, with its roots in the preaching of the gospel of Christ by the Africa Inland Mission (AIM), which started in 1895 (Background n.d). Its mission is based on fulfilling the great commission of Matthew 28:19-20, proclaiming Christ (Col 1:28) as its vision. The AIC's five aims are evangelism, discipleship, teaching, missions and engaging in selective community development projects as a means to show and demonstrate Christ's love and concern for people (Mission, Vision \& Aims n.d).

The AIC has five departments, namely the AIC Health Ministries (AICHM), Biblia Husema Broadcasting, AIC Missions, Christian Education and AIC Childcare (Departments n.d). Two of the five departments, namely the Biblia Husema and Christian Education, do not appear to be explicitly concerned with social issues. The Biblia Husema is a broadcasting department that uses radio for evangelism, preaching, religious music and interviews. Its mission is to communicate the good news of salvation, while its vision is to influence its listeners through Christ-centred discipleship (About us n.d). The Christian Education Department generates and distributes devotional, discipleship and training literature for use by various groups within the church, including managing all theological institutions run by or affiliated to the AIC (Christian Education n.d).

The other three departments, namely the AICHM, AIC Missions and AIC Childcare have aspects of social life as their areas of operation. The agenda of the AICHM is the provision of a combination of spiritual and healthcare services to people living in rural and remote areas in Kenya. It has five hospitals and 52 health centres, making it one of the leading providers of healthcare in Kenya. The active participation of the church in the provision of medical care is motivated by a desire to demonstrate Christ's love to people in Kenya, including empowering communities to enjoy quality lives and find wholesomeness in Christ (About AICHM n.d). The AIC Missions Department is arguably the largest mission agency in Kenya, with over a 100 sent missionaries since 1958. It has started a number of churches and primary schools amongst hitherto unreached communities in Kenya. It also facilitates the provision of relief foods as well as the construction and running of dispensaries and health clinics in remote areas. Church-planting, including the construction and running of primary schools and health care facilities in unreached remote areas, is motivated by a desire to evangelise and make disciples of the locals (AIC Missions Department n.d). The AIC Childcare Department provides support services to vulnerable children, youth and households. Provision of food and education, including spiritual nurture and livelihood support to vulnerable households is done through institutional care (children's homes), youth vocational skills programmes and communitybased programmes (AIC Childcare Department n.d).

Kenya, the primary context of the AIC, is a land of many contrasts. According to UNICEF (n.d:1 of 1), Kenya is arguably one of the most unequal countries in Eastern Africa, with $42 \%$ of its 44 million people living below the poverty line. Access to healthcare, education, clean water and sanitation remains a luxury for many.

More than three-quarters of Kenya's population live in rural areas and rely on agriculture for most of their income. Poverty and food insecurity are acute in the country's arid and semiarid areas. Kenya also has one of the world's highest rates of population growth. The population has tripled in the past 35 years, increasing pressure on the country's resources and leaving young people particularly vulnerable to poverty. Rural women are vulnerable, because they do not have equal access to social and economic assets. Rural poverty in Kenya is also strongly linked to environmental concerns, especially poor water management, soil erosion, declining soil fertility and land degradation. Climate change, which is one of the major challenges facing the Kenyan economy, could undermine the resource base and contribute to declining agricultural yields. Droughts and floods have increased in frequency and intensity over the last decade (IFAD 2014).

Urban poverty is a real challenge in Kenya. Indeed, between 30 and $55 \%$ of those living in urban areas actually live in slums. Urbanisation continues to be poorly managed, leading to massive expansion of overcrowded and impoverished informal settlements. Access to basic services such as water, electricity and infrastructure tends to be minimal or even non-existent for the majority of the urban poor. It is estimated that $94 \%$ of the population of informal settlements do not have access to adequate sanitation. Water is only provided to a few at high prices. Similarly, solid waste generated in these areas has outstripped the capacity to provide adequate and efficient waste management services (Poverties.org 2012; SIDA 2010). 
In addition, Kenya faces humanitarian challenges due to the presence of over 500000 refugees from Somalia and another 300000 from South Sudan. Drought and food insecurity remains a reality. There is also increasing insecurity caused by extremist elements, especially Al-Shabaab (UNICEF n.d:1 of 1).

Other factors that continue to impoverish a number of Kenyans and deepen poverty include alcoholism and drug addiction, family size (as in having many dependants in need of care), small land holding and uneconomical subdivision of land, death of income earners, lack of inheritance, marriage expenses, expenses related to funerals (as in slaughtering of family livestock) and poor health and health related expenses (Krishna et al. 2004:221-222; Kristjanson et al. 2010:990-991). Improving healthcare provision can constitute the single most important aspect for poverty intervention.

In 2010, Kenya enacted a new constitution that attempts to respond to long-standing historical, geographical, demographic and human rights challenges that have hindered growth and progressive development in Kenya. Under the new constitution, power has been devolved from the national government to 47 new decentralised counties, with an expectation of equitable allocation of resources and an accountable service delivery.

It is within such a context that an enquiry on the efficacy and value of the poverty discourses in public theology is made. The AIC needs an enabling theological framework that can assist it to responsibly and adequately engage the challenge of poverty. The uniqueness of AIC's mission amongst the poor and the vulnerable is commendable. AIC's provision of a combination of spiritual and social service, motivated by the desire to demonstrate Christ's love, including empowering communities to enjoy quality lives and find wholesomeness in Christ, is distinct and remarkable. However, due to the high levels of poverty, there is a need to enhance and refine the way that the AIC provides its services, particularly in response to the challenge of poverty.

\section{A theoretical framework: The notion of public theology}

The notion of public theology is a relatively new one. Although there is still no universally agreed definition, it is a global enterprise with opportunities to study it. In each region of the world, it appears in slightly different guises, and exhibits varying priorities and emphases. Nevertheless, most of its conceptions share important fundamental assumptions, so that it is possible to speak of a consensus understanding of the term and to identify its core features (Bradstock 2011:225; Breitenberg 2010:4). Bradstock (2011:225) traces public theology to Martin Marty who is claimed to be the first person to speak intentionally and sketch out a description of public theology. Included amongst those who built on Marty's foundation are David Hollenbach and David Tracy (Bradstock 2011:225-226; Breitenberg 2010:9). David Hollenbach spoke in 1976 of the need for public theology to attempt to 'illuminate the urgent moral questions of our time through explicit use of the great symbols and doctrines of the Christian faith'. David Tracy argued that 'theology is public discourse' and that every theologian should address three 'publics' or 'distinct and related social realities', namely 'wider society, the academy, and the church'. In the UK, Duncan Forrester has done significant pioneering work in public theology, which, according to him, has a concern to 'discern the signs of our times and understand what is going on in the light of the gospel', and speaks of it 'contributing to public discussion by witnessing to a faith that is relevant to what is going on in the world and to the pressing issues which are facing people and societies today' (Forrester 2004:431).

Although the notion is new, what it represents is what Christians have always been called to practice (Bevans 1996:3, 15). Kim (2011:viii) disputes the argument that the notion of public theology is a new one. He argues that public theology is not a new concept as Christian theology has always tried to be relevant to its context and society. Nevertheless, with the privatisation of religion, particularly in the West, public theology has emerged in theological discourses.

Although it is a notion that remains disputed, it may be deduced from various writers (Benne 1995:3; Bradstock 2011:226; Breitenberg 2003:66; Forrester 2000:127-128, 2004:6; Kim 2011:viii; Moltmann 1991:1; Stackhouse 1997:167; Thiemann 1991:21; Tracy 1998:350-356) that public theology is concerned with the fabric of present-day life. It deals with public relevance of theology by getting involved in public affairs. It pursues what is of general concern in light of the hope in Christ. It seeks to discern the signs of the times so as to offer convictions and insights that are derived from the Christian tradition. It seeks the welfare of the society by taking the world's agenda (or part of it) as its own and seeks to offer distinctive and constructive insights from the treasury of faith for the building of a decent society and the restraint of evil. It is a theologically informed discourse on public issues addressed to religious bodies and the larger society, and is argued in ways that can be accessed and assessed by publicly available warrants and criteria. It is concerned with bringing a theological perspective to bear upon contemporary debates in the public square, drawing upon the insights of the Christian faith and offering its contribution as a 'gift' to the secular world. It seeks to converse with citizens on issues wider than religious matters and urges Christians to participate in the public domain.

These descriptions of public theology highlight three key aspects (Bradstock 2011:226-238). The first aspect refers to the language of 'gift' that recognises the marginal location of Christian faith in a post-Christian world. Theology makes a contribution to the public square simply as one contributor alongside other disciplines. Accepting the marginal nature of the Christian faith requires an acknowledgement of the limitations and inadequacy of its own resources and it has to engage seriously with those disciplines relevant to the issues at hand. Public theology needs to be a theologically informed discourse. 
The second aspect involves public theology's drawing from a rich variety of sources such as scripture, historical creeds of the church, the teachings of the church fathers and the contributions to the interpretation and understanding of the faith offered by luminaries and councils within the Catholic, Protestant and Orthodox traditions. Public theology handles biblical texts in a way that the first Christians and the gospel writers did, that is, by prioritising, not the letter of the law (which kills), but being open to what might be its deeper meaning as disclosed by the Spirit (which gives life) (2 Cor 3:6).

The third aspect relates to 'contributing to contemporary discourse in the public square'. Public theologians acknowledge that their work should be understandable to those outside (and within) their faith tradition. According to Breitenberg (2010:6), Max Stackhouse and Elaine Graham (Graham 2007:54), public theology must find ways of communicating with people at large. This means that theology learns the discourse of the secular world while also digging deep into its own resources.

The challenge of public theology is to find ways of speaking both to the church to help it rediscover its original calling to transform the world, and in the public square where it has much to contribute to the transformation process. Public theology seeks to bring scripture to bear on issues in the real word - a task that can be undertaken by ordinary believers as much as by 'professional' theologians and clergy. It creates opportunities for 'speaking truth to power' and it seeks to make a difference to people and situations. It is about demonstrating that authentic faith concerns actions and not just words, changing the word rather than redefining or interpreting it (Bradstock 2011:225, 238). It is about public conversations that contribute to the formation of personal decisions and collective policy-making in economic, political, religious and social realms (Kim 2011:3).

The increase of secularism globally (Kim 2011:x-xi) presents an urgent need for Christian theology to be actively engaged in conversations within the public sphere, even though Christian theology does not have all the answers to the issues in the public domain. However, Christian theology becomes a voice that puts forward moral, ethical and spiritual insights that make vital contributions to addressing problems for the promotion of the common good in modern societies.

\section{Approaches to public theology}

Although public theology shares similar characteristics with other theological discourses such as political theology, social ethics and liberation theology, it has established its own distinctive ways to engage in public issues. Its methods are, however, constrained and shaped by the variety of different social and political contexts in which it is done (Kim 2011:3, 14). Although there are various approaches to doing public theology, two approaches stand out: the first is direct and explicit involvement of churches in public matters in all spheres of public life, and the second deals with the practices of the local congregation that impact on public life.

\section{Direct involvement}

The direct involvement approach to doing public theology entails an articulation of corporate conscience for the purposes of direct, intentional influence that may include exercise of power or direct intentional actions. Notable proponents of this approach include Robert Benne (1995), Dieter Hessel (2002:1), Max Stackhouse et al. (1995) and Stackhouse, Dearborn and Paeth (2000), for example, writes that the church should give special attention to regaining and enlivening contextual theological focus in a rapidly changing society, formulation and teaching of a coherent social ethic and the development of a vigorous witness to the nation that would better utilise ecclesial resources and mobilise members to carry out this mission.

Direct public engagement is about Christian theology getting out of the church's space to public places of debate. This approach seeks to engage with the social, political and spiritual issues of the day, bringing a coherent Christian perspective to bear upon public policy and cultural discourse through intentional influence or intentional action. It is about a credible and intelligible voice from the church that utilises ecclesiastical resources to formulate and teach a coherent social ethic. It is about the church's vigorous role as a witness to the nation, which in some instances may adopt the use of power (Benne 1995:202-224; Hessel 2002:1-83; Koopman 2003:4; Stackhouse et al. 2000:7-8; 1995:950-951).

The direct involvement approach is complemented by another approach that focuses on the public significance of congregational practices that have an impact on public life, namely the indirect involvement approach.

\section{Indirect involvement}

Some of the key proponents of this approach to doing public theology include Stanley Hauerwas, George Lindbeck, Hans Frei, Paul Holmer and Ronald Thiemann. This approach rejects any endeavours to make Christian beliefs universally reachable by explaining or decoding them in existentialist, Marxist, pragmatist, idealist or any other terms supposed to be more familiar to those in the public arena. It emphasises faithfulness towards the language used in the Christian communities (Comstock 1986:129; Conradie 1993:38-40; Placher 1985:410).

In several of his books, Hauerwas (1981:190-191; 1983:108; 1995:185; Hauerwas \& Willimon 1998:19-20) discusses congregational practices that he suggests have considerable significance to public life, namely Baptism and Eucharist, prayer, preaching, pastoral care and discipline as well as the way Christians deal with sexual matters. These practices, Hauerwas argues, have an impact on public life and are crucial in the formation of character and habits. As such, the church prepares its communicants as individuals to deal with issues in the wider society.

Within this approach, Baptism and Eucharist are seen as motives, causes for social action and are in themselves 
effective social work. In Baptism and Eucharist humanity sees the marks of God's kingdom in the world. Through prayer Christians learn to open themselves to God and it is their most important civic responsibility that lets God loose in the world. Preaching forms Christians into a people of witness by challenging people with the story of Jesus and his kingdom and helping them to hear and see in new ways. Through pastoral care and discipline, the church becomes a holy community in the world that is capable of leading a life of compassion, hospitality and justice. Sexual behaviour is seen as not private but public, as what people do to their bodies have an impact on the body of Christ - a body of which one becomes a member through baptism and which also affects the larger society (Hauerwas 1995:121, 185; 1983:109; Hauerwas \& Willimon 1998:19-20).

This approach is more inward looking. It anticipates the enhancement of internal congregational practices, which, in turn, have an impact on the life of a Christian in the public arena. It relies on the participation of individual Christians to respond to issues in society as they live their lives wherever they are.

The aforementioned two approaches to doing public theology, notwithstanding, it has been pointed out (Kim 2011:19-20) that there is not just one public to which public theology relates, but several different publics and different approaches are required to address each of them. Stackhouse et al. (1995:165-179) identifies four publics, namely the religious, political, academic and economic publics. Koopman (2003:9) identifies political, economic, civil society and public opinion as four distinct discourses in public theology. Elliot (2007:290-305) discusses three different publics, institutional public, constructive public and personal public, each of which draws distinctive theological assumptions about church and faith.

In the words of Stackhouse et al. (2000:18), the message of the church has to be convincing or else people will cease to attend it. They may even decide against it or subvert it and turn to other authorities, ideologies or faiths. The work of the church has to be done through persuasion or it will not work at all.

\section{Poverty in public theology}

According to Moltmann (1999:2-23), theology, in light of the hope in Christ, has to exhibit general concerns for the kingdom of God by being political in the name of the poor and marginalised. Theology must allow space for critical thinking about the religious and moral values of the society it exists in and present its reflections as a reasoned position. Theology has to be a critical, prophetic, reflective and reasoned engagement within a community for the sake of the poor and marginalised to bring them to the Kingdom of God.

In the indirect involvement approach, the focus is on the significance of congregational practices for public life. As such, poverty within the church is attended to (Osmer 2001:37-75). The needs of the poor within the church are addressed, while individual believers are prepared to deal with poverty within the larger society (Schweiker 2000:138). This approach draws on the practices of the congregation to address poverty in and outside the church. Through the celebration of Baptism and the Eucharist, Christians are reminded that they are one body in Christ and have to share what they have with the rest of humanity, especially the poor. Through prayer, Christians open themselves to God and what God wants to be done, including caring for the poor. Preaching and biblical narratives, especially the story of Jesus, enable Christians to hear and see in new ways. They therefore become aware of the needs around them and respond accordingly. Compassion, holiness and justice are entrenched through pastoral care and discipline. How Christians deal with sexual matters is a pointer to faithfulness, representative of God's unrelenting commitment to bring restoration to all humanity. These ordinary congregational practices are crucial in the formation of character and habits that assist Christians to deal with poverty.

In the direct involvement approach, the focus is on how to influence public discourse and opinion, including analysis, policy making, advocacy and intentional public action (Verhey 2001:137-138). The concerns of the poor are attended to in various ways. Churches issue statements aimed at the wider public on poverty issues (Stackhouse et al. 2000:16). Churches lobby policy makers to mobilise support for legislation. Advocacy on behalf of the poor is central to the church's role, including mobilisation of the masses directly for action against poverty with the hope of transformative change. Koopman (2010) provides an example:

Various local congregations in South Africa had started to establish discussions where policy issues are being dealt with. Churches, however, need also to participate more directly and institutionally in public policy process. The South African Council of Churches (SACC), the South African Council of Catholic Bishops Conference, the Dutch Reformed Church, as well as the Baptist Church and the Society of Friends (Quakers) had established public policy liaison officers at the national parliament during the past decade. These churches collaborate on issues of public policy. They make presentations to the portfolio committee of parliament, and they guide, inform and consult with churches (from ecumenical to congregational level) on specific policy issues. (pp. 43-44)

It must be noted that if the role of public theology in the public policy-making discussion forums is merely the provision of broad principles, the concerns of the poor may not be adequately represented. Public theology has to bring specific directives for policy making.

Public theology therefore deals with instances of poverty mainly from both the perspective of the impact of congregational practices, which shape a character that is alive to the reality of poverty and the perspective of influencing public discourses and opinions through the analyses of social contexts, advocacy, formulation, monitoring and evaluation of policies that seek to respond to instances of poverty. 
Although poverty is attended to in public theology, the role, place and priority of the poor, however, cannot be said to be very explicit. Public theology largely deals with debates and engagements in the public square just as Forrester (1997) pleaded that poverty had to be addressed through public theological engagements. Both of the two approaches to doing public theology (direct and explicit involvement, and indirect and non-explicit involvement attend to poverty), however, do attend to poverty.

\section{Implications for the Africa Inland Church}

Public theology's desire to gain entry to the debates in the public square, which is deeply concerned with intelligibility, can be the very feature that may actually make it neglect to attend directly to issues of poverty. As indicated earlier, the agenda of public theology is to gain an entrée into debates in public spaces. It is critical of any use of utopian language, including mere criticism as a mode of engaging in public life. Although Kenya has arguably one of the lowest adult illiteracy rates in Africa at 27\% according to UNESCO (2015:1 of 1), illiteracy continues to be high in poorer regions, rural areas and unplanned settlements (slums). These are areas where the AIC has some of its church-planted schools, healthcare facilities and children's homes. There is a need to ensure that the voices of the illiterate poor are heard in local and national public debates. Public theology's agenda of gaining entry into public debates can assist the AIC to reflect deeply on how to be a voice of the illiterate poor in local and national public forums where development agenda are discussed.

Public theology abhors mere criticism as a mode of engaging in public life. Mere criticism is unhelpful and even counterproductive in public discourse. Reasoned engagement and awareness that the church is one of the voices are key to influencing public opinion and action for good. Although Kenya has progressively become a free country where there is an ever-increasing respect for human rights, it was through the efforts of various churches and civil society in the 1990s that the masses were marshalled against the governments of the time to change oppressive laws that had dehumanised and impoverished sections of the Kenyan population and regions of the country. The Kenyan Catholic, Presbyterian and Anglican churches played a pivotal role in offering reasoned criticism against the leadership of the time (Patel 2001:163; Troup, Sabir-Friedman \& Abuom 2002). Curiously, the voice of the AIC was missing and continues to be unheard even in times of national crisis such as the 1997-1998 postelection conflicts (Mwaura \& Martinon 2010:40-43), which led to deaths, dispossession and impoverishment of many households. The Biblia Husema Broadcast Department's radio facility can be an excellent tool to engage communities and devolved governments to build cohesion and speak with and for the vulnerable.

Poverty is indeed given attention to in public theology through its emphasis on the analysis of social contexts, participation in public discourse, public policy formulation and monitoring. It also includes its emphasis on the significance of congregational practices of addressing poverty within the church and the wider society. It is commendable that the AIC has on-going healthcare facilities and schools amongst various unreached communities. Provision of healthcare and education in remote areas has become an effective means to evangelise and make disciples for Christ. The provision of health services and education, amongst other services, benefit more people in instances where there is a closer cooperation between the AIC and the local devolved government departments. Presently, the AIC, by and large, has a tendency to providing social services in poor communities using its own independent assessments and research, and in closer cooperation with churches mainly from the USA, UK, Canada and the Scandinavia countries. This approach, presents an appearance of a parallel independent service provider, which in some instances duplicates services on offer by the devolved government departments. An informed, closer and complementary cooperation with local institutions, as argued for in public theology, becomes a better alternative. By participating in local public discourse, which is informed by contextual social analysis and in partnership with the devolved government departments, allows for partnership and complementarity.

Public theology's emphasis on rational and credible participation in public discourses can help churches to make a more adequate impact on poverty and public policies and practices. To the AIC, public theology is that 'relevant theology' that enables it to engage with the lived realities of the people it serves. Nyiawung (2010:1) has, for example, observed that most African countries have embraced democracy without defining its contents, which may thus lead to unpredictable consequences in communities where the leaders cherish what they gain from leadership rather than service to those communities. For the AIC, emphasis on rational and credible participation in public discourse is critical to mitigating over-concentration on evangelism and discipleship, on the one hand, and, on the other hand, responding to the challenges faced by the poor and vulnerable communities.

\section{Conclusion}

The AIC certainly needs a theology, perhaps theologies, which could enable it to respond more faithfully to the triune God regarding poverty in Kenya and in the world. Although public theology may not be the be-all and end-all, its agenda, its emphasis and its approaches as well as the place and priority of the poor in it, makes public theology an emerging means by which the AIC can, at present, engage the challenge of poverty.

Although the AIC has a very long history of just over 120 years in Kenya, and although it runs schools, healthcare facilities and children's homes in remote rural areas amongst the poor, its main motivation has been the evangelisation and discipleship of peoples and communities. With its vast 
resources, that is, land, magnificent church buildings, healthcare facilities, schools, theological institutions, colleges and a university, the AIC can do more in Kenya to fight poverty and its dehumanising effects.

Public theology, with its emphases and approaches, could become the mechanism by which the AIC could reposition itself in present-day Kenya. Since the adoption of the 2010 constitution in Kenya, the AIC has had to find ways of complementing the contributions of both the national and county governments in the fight against poverty. The AIC has to find an entrée into Kenya's public square, albeit with humility, as one of the voices. It must be prepared, however, to engage other stakeholders on policy making, policy implementation and policy monitoring - all for the sake of the poor, and consistent with the calling of the church to address poverty and its dehumanising effects in Kenya and globally.

In an effort to contribute to poverty intervention, we recommend that the AIC engages in the forgoing.

First, gain an entrée and maintain a presence in the public square. The AIC will serve the poor and the vulnerable more effectively by ensuring that it has a presence in the public arena. The church could do this by not only attending to public engagements in the public square, but by also opening up church spaces for community discourses, programs and events.

Second, adopt the agenda of the poor and vulnerable. Motivated and guided by Christ's Great Commission in Matthew 28:18-20:

Then Jesus came to them and said, 'All authority in heaven and on earth has been given to me. Therefore go and make disciples of all nations, baptizing them in the name of the Father and of the Son and of the Holy Spirit, and teaching them to obey everything I have commanded you. And surely I am with you always, to the very end of the age.' (NIV)

and Colossians 1:28, 'He is the one we proclaim, admonishing and teaching everyone with all wisdom, so that we may present everyone fully mature in Christ' (NIV), the AIC has to embrace the programmes and causes of the poor as its own, in order to effectively partner in the fight against the causes and effects of poverty.

Third, the AIC has to participate in rational and public discourses. This endeavour will position the church to effectively and contextually respond against poverty with and for the poor.

\section{Acknowledgements Competing interests}

The author declares that he has no financial or personal relationships which may have inappropriately influenced him in writing this article.

\section{References}

About AICHM, n.d., AIC health ministries, viewed 22 September 2015, from http:// www.aichm.org/index.php/who-we-are/about-us

About us, n.d., Truth FM, viewed 21 September 2015, from http://truthfm.org/ about-us

AIC Childcare Department, n.d., Africa Inland Church Kenya, viewed 22 September 2015, from http://www.aickenya.org/departments/?ContentID $=5$

AIC Missions Department, n.d., Africa Inland Church Kenya, viewed 22 September 2015, from http://www.aickenya.org/departments/?ContentID=3

Background, n.d., Africa Inland Church Kenya, viewed 21 September 2015, from http://www.aickenya.org/about_us/?ContentID=1

Benne, R., 1995, The paradoxical vision: A public theology for the twenty-first century, Fortress, Minneapolis, MN.

Berryman, P., 1987, Liberation theology: Essential facts about the revolutionary movement in Latin America and beyond, Temple University Press, Philadelphia, PA.

Bevans, S.B., 1996, Models of contextual theology, Orbis Books, New York.

Bradstock, A., 2011, 'Seeking the welfare of the city: Public theology as radical action', in Z. Bennett \& D. Gowler (eds.), Radical Christian voices and practice: Essays in Honour of Christopher Rowland, pp. 225-240, Oxford University Press, Oxford.

Breitenberg, E.H., 2003, 'To tell the truth: Will the real public theology please stand up?', Journal of the Society of Christian Ethics 23(2), 55-96.

Breitenberg, E.H., 2010, 'What is public theology?', in D.K. Hainsworth \& S.R. Paeth (eds.), Public theology for global society, pp. 3-19, Eerdmans, Grand Rapids, ML.

Christian Education, n.d., Africa Inland Church, viewed 21 September 2015, from http://www.aickenya.org/departments/?ContentID=4

Comstock, G.L., 1986, 'Truth or meaning: Ricoeur versus Frei on Biblical Narrative', Journal of Religion 55(4), 129. http://dx.doi.org/10.1086/487357

Conradie, E.M., 1993, 'How should a public way of doing theology be approached?', Scriptura $7(46), 24-49$.

Departments, n.d., Africa Inland Church Kenya, viewed 21 September 2015, from http://www.aickenya.org/departments

Elliot, A., 2007, 'Doing theology: Engaging the public', International Journal of Public Theology 1(3), 290-305. http://dx.doi.org/10.1163/156973207X231635

Forrester, D.B., 1997, Christian justice and public policy, vol. 10, Cambridge University Press, Cambridge.

Forrester, D.B., 2000, Truthful action, T\&T Clark, Edinburgh.

Forrester, D.B., 2004, 'Working in the quarry: A response to the colloquium', in W.F. Storrar \& A.R. Morton (eds.), Public theology for the 21st century: Essays in Honour of Duncan B. Forrester, pp. 431-438, T\&T Clark, London.

Frankema, E.H.P., 2012, 'The origin of formal education in sub-Saharan Africa: Was British Rule more Benign?', European Review of Economic History 16(4), 1-21. http://dx.doi.org/10.1093/ereh/hes009

Garner, R.C., 2000, 'Religion as a source of social change in the new South Africa', Journal of Religion in Africa 30(3), 310-343. http://dx.doi.org/10.1163/ $157006600 \times 00555$

Graham, E., 2007, 'Power, knowledge and authority in public theology', International Journal of Public Theology 1(1), 42-62. http://dx.doi.org/10.1163/156973207X194484

Hauerwas, S., 1981, A community of character: Toward a constructive Christian socia ethic, University of Notre Dame Press, Norte Dame.

Hauerwas, S., 1983, The peaceable kingdom: A premier in Christian ethics, University of Norte Dame Press, Notre Dame.

Hauerwas, S., 1995, In good company: The Church as polis, University of Notre Dame Press, Notre Dame.

Hauerwas, S. \& Willimon, W.H., 1998, The truth about God: The ten commandments in Christian life, Abingdon Press, Nashville, TN.

Hessel, D.T. (ed.), 2002, The church's public role: Retrospect and prospect, Wipf \& Stock Publishers, Eugene, OR.

IFAD, 2014, Rural poverty in Kenya, viewed 22 September 2015, from http://www. ruralpovertyportal.org/country/home/tags/kenya

Kim, S., 2011, Theology in the public square: Public theology as a catalyst for open debate, SCM Press, London.

Kim, S. \& Kim, K., 2008, Christianity as a world religion, Continuum, London.

Koopman, N., 2003, 'Some comments on public theology', Journal of Theology for Southern Africa 16(117), 3-19.

Koopman, N., 2010, 'Churches and public policy discourses in South Africa', Journal of Theology for Southern Africa 136(1), 41-56.

Krishna, A., Kristjanson, P., Radeny, M. \& Nindo, W., 2004, 'Escaping poverty and becoming poor in 20 Kenyan Villages', Journal of Human Development 5(2), 211-226. http://dx.doi.org/10.1080/1464988042000225131

Kristjanson, P., Mango, N., Krishna, A., Radeny, M. \& Johnson, N., 2010, ‘Understanding poverty dynamics in Kenya', Journal of International Development 22(7), 978-996. http://dx.doi.org/10.1002/jid.1598

Mission, Vision and Aim, n.d., Africa Inland Church Kenya, viewed 21 September 2015 from http://www.aickenya.org/about_us/?ContentID=2

Moltmann, J., 1991, History and the triune God, SCM, London. 
Moltmann, J., 1999, God for a secular society: The public relevance of theology, Fortress Press, Minneapolis, MN.

Mwaura, P.N. \& Martinon, C.M., 2010, 'Political violence in Kenya and local churches' Responses: The case of the 2007 Post-Election Crisis', Review of Faith and International Affairs 8(1), 39-46. http://dx.doi.org/10.1080/15570271003707812

Nyiawung, M.D., 2010, 'The prophetic witness of the church as an appropriate mode of public discourse in African societies', HTS Teologiese Studies/Theological Studies 66(1), Art. \#791, 8 pages. http://dx.doi.org/10.4102/hts.v66i1.791

Osmer, R., 2001, 'The teaching ministry in a multicultural way', in M. Stackhouse \& D.S. Browning (eds.), In God and globalization: The spirit and the modern authorities, vol. 2, pp. 37-75, Trinity Press International, Harrisburg, PA.

Patel, P., 2001, 'Multi-party politics in Kenya', Revista Ciencia Politica 21(1), 154-173.

Placher, W.C., 1985, 'Revisionist and postliberal theologies and the public character of theology', Thomist: A Speculative Quarterly Review 49(3), 392-410.

Poverties.org, 2012, Poverty in Kenya: The impact of unemployment, Child labor \& HIV viewed 29 September 2015, from http://www.poverties.org/poverty-in-kenya.html

Schweiker, W., 2000, 'Responsibility in the world of mammon', in M. Stackhouse \& P. Paris (eds.), God and globalization: Religion and the powers of the common life, vol. 1, pp. 105-139, T\&T Clark International, NY.

SIDA, 2010, Urban poverty: A dynamic challenge, viewed 29 September 2015, from http://www.swedenabroad.com/ImageVaultFiles/id_8757/cf_347/ SIDA52620en_Urban_poverty_a_dynamic_challenge_webb.PDF

Stackhouse, M.L., 1997, 'Public theology and ethical judgment', Theology Today 54(2), 165-179. http://dx.doi.org/10.1177/004057369705400203
Stackhouse, M.L., Dearborn, T. \& Paeth, S. (eds), 2000, The local church in a globalizing era: Reflections for a new century, William B. Eerdmans Publishing Company, Grand Rapids, MI.

Stackhouse, M.L., McCann, D.P., Roels, S.J. \& Williams, P.N., 1995, On moral business: Classical and contemporary resources for ethics in economic life, William B. Eerdmans Publishing Company, Grand Rapids, MI.

Thiemann, R.F., 1991, Constructing a public theology: The church in a pluralistic culture, Westminster/John Knox Press, Louisville, KY.

Tracy, D., 1998, The analogical imagination: Christian theology and the culture of pluralism, Crossroad, NY.

Troup, D., Sabir-Friedman, G. \& Abuom, A.C., 2002, 'The church's involvement in the democratization process in Kenya', in G. Wachira \& H. Asefa (eds.), Peacemaking and democratization in Africa: Theoretical perspectives and Church initiatives, pp. 95-116, East African Educational Publishers Ltd., Nairobi.

UNESCO, 2015, Youth and adult literacy, viewed 30 September 2015, from http:// www.unesco.org/new/en/nairobi/education/youth-and-adult-literacy

UNICEF, n.d., Kenya at a glance, viewed 29 September 2015, from http://www.unicef org/kenya/overview_4616.html

Van Klinken, A.S., 2010, 'When the body of Christ has AIDS: A theological metaphor for global solidarity in light of HIV and AIDS', International Journal of Public Theology 4(4), 446-465. http://dx.doi.org/10.1163/156973210X526418

Verhey, A., 2001, 'The Spirit of God and the Spirit of medicine: The Church, globalization, and a mission of health care', in M.L. Stackhouse \& D.S. Browning (eds.), God and globalization: The spirit and the modern authorities, vol. 2 pp. 107-138, Trinity Press International, Harrisburg, PA 